\title{
AN ASSESSMENT OF NIGERIA'S AGRICULTURAL CREDIT GUARANTEE SCHEME FUND: EVIDENCE FROM TIME-SERIES ANALYSIS
}

\author{
X. A. OKON AND N. M. NKANG*
}

(Received 2 June, 2008; Revision Accepted 24 November, 2008)

\begin{abstract}
The operations of Nigeria's Agricultural Credit Guarantee Scheme Fund (ACGSF), after twenty-seven years, were subjected to macro econometric analysis, presumably the first quantitative approach to the scheme, with the objective of providing useful results, deducing policy implications, and perhaps, policy options. Specifically, the volume by number and value of loans guaranteed and repaid, with the addition of a credit-determining policy instrument, were modelled using vector autoregression (VAR) methodology to evaluate the economic information they contain and their relevance in terms of policy analysis. The value of loans guaranteed was identified to be positively related to the number of loans guaranteed and the number and value of loans repaid, and inversely related to the policy instrument. In this light, the managers of the scheme need to step up and encourage vigorous repayment of loans under the guarantee and develop capacity to process and approve guarantees and default claims on-line. Beyond these, the monetary policy regulating institution is urged to adopt forward looking rules, example, by encouraging participating banks to access the discount window at favourable terms, that do not directly or indirectly infringe on the expressed aims of the ACGSF, say, in its attempt at affecting the liquidity (interest rate) and/ or credit channels of monetary transmission.
\end{abstract}

KEYWORDS: Credit, guarantee, agriculture, vector autoregression, monetary policy.

\section{INTRODUCTION}

In 1977 the Federal Government of Nigeria, through the Central Bank of Nigeria (CBN) established the Agricultural Credit Guarantee Scheme Fund (ACGSF) for the purpose of improving access to farm credit, in realization of the invaluable role agriculture plays in the economy, and the view that credit is an important tool for raising incomes of farmers and rural people, especially by mobilising resources to more productive uses (Atieno, 2001).

The Scheme which became operational in 1978 provides 75 per cent guarantee cover for lending banks on outstanding loan balance in event of default. The introduction, over the years, of Self Help Group (SHG) Linkage Banking, Trust Fund Model (TFM) and Interest Drawback Programme (IDP) into the scheme by the CBN was to make the scheme more appealing to both the lenders and the borrowers and, above all, meet the ends of increased agricultural productivity and economic development.

As the CBN's flagship development financing scheme, the ACGSF has lived through the paradigm contrasts of regulation and deregulation. In the era of credit rationing, preferred sectors and statutory interest rates, banks were obliged to lend under the scheme or be penalized for failure to do so. With liberalization, banks had the discretion of choice of loan portfolios to invest in and, like in many similar circumstances, agriculture was the least likely to attract their attention.
Whether there was stability or structural breaks in the level of credit availed borrowers by banks under the scheme before and after deregulation is subject to empirical investigation.

By 2005 , the loans guaranteed stood at over N10billion, corresponding to about 443, 660 loans. Loans fully repaid totalled N6billion in value and 310 , 653 , in number, by the same year representing 60.08 per cent and 70.02 per cent respectively of the value and number guaranteed. The statistics cut across all major crop and livestock enterprises, including long gestation tree crops. The CBN emphasizes high volumes of loans guaranteed and repaid, to the extent that both indices, among others, form part of appraisal of the ACGSF scheme as well as that of its development finance officers. This is quite in line with the concept of guarantee which is intended to expand lending and induce high repayment performance.

An inquiry into the performance of the ACGSF has become almost inevitable following the perceived poor performance of the scheme even in the face of various incentive schemes introduced to leverage it in the past years, as evident in the fact that the banks still extend a large chunk of credit to agriculture outside the ACGSF. For example CBN's statistics show that it was in 1979 that the percentage of guaranteed agricultural credit relative to total commercial banks' credit to agriculture peaked, at only 10.10 per cent from 1977 . This proportion has largely been on the decline since then and was lowest in 1999 with 0.21 per cent. Again,

X. A. Okon, Development Finance Office, Central Bank of Nigeria, Owerri, Imo State

*N. M. Nkang, Department of Agricultural Economics and Extension, University of Calabar, P. M. B. 1115, Calabar, Nigeria

Note: The views expressed in this paper are those of the authors and should not be interpreted as reflecting the views of the Central Bank of Nigeria or the University of Calabar. 
the current assessment is justified following the position of Hollinger (2004:117) that the ACGSF "... was virtually moribund by 1996 . [It] survived only by defaulting on claims, so the volume of guarantees fell to insignificant amounts". In other words, there is need to explore the internal and, possibly, policy factors (in relation to the scheme), say, monetary policy, which is in the CBN's purview, that banks respond to, in making ACGSF loans, especially as banks have a rather unimpressive record of participation in the scheme. This unimpressive record is made even worse by imperfect information in the credit markets - especially in credit guarantee schemes - which leads to the problems of credit rationing, adverse selection and moral hazard (Stiglitz and Weiss, 1981; Oboh, 1981; Besley, 1994 and ODA, 1997).

Furthermore, this study is imperative from two points of view. First, assuming that the associated innovations in the ACGSF trickle into its operations through the volume of loans guaranteed and repaid, the CBN would wish to know if they have been effective as a means of getting more bank loans to farmers. Second, from the bank lending channel view of monetary transmission, we need to assess how food producers will be favoured or otherwise with bank credit following specific monetary policy actions.

Consequently, this study attempts to use vector autoregression approach to investigate the following research questions:

i. what are the main features and structure of the ACGSF?

ii. what is the direction and magnitude of the relationship between the CBN target indicators of the scheme and the value of loans guaranteed;

iii. What has been the influence of monetary policies and associated shocks on the value of loans guaranteed?

The rest of the paper is structured as follows. Section two presents the theoretical framework and conceptual issues. The next section provides the analytical framework for the study. Section four discusses the estimated results while the last presents the policy implications.

\section{THEORETICAL AND CONCEPTUAL ISSUES}

\section{The Concept of Credit Guarantee}

The ACGSF is founded on the principle of guarantee, aimed at sharing risk so as to overcome the resistance of financial institutions to lending to targeted borrowers. A guarantee programme insures repayment of loans, in full or in part, in order to motivate lenders to lend to groups, such as small farmers, small and medium enterprises, women and the poor, who would not have access to credit under normal circumstances (Navajas, 2001). Formal financial institutions are averse to lending to these groups of people they consider as "risky" because of stagnant agricultural markets, high production risk and perceived low profitability of farming, lack of collateral, and their poor financial recording systems (FAO, 2006). These guarantees are aimed at stimulating lending to credit-worthy borrowers with feasible projects, but lack sufficient assets to offer as collaterals (Reichmuth, 1997).
In this arrangement, the parties have specific obligations - the lender making more and more loans, albeit with due diligence, the borrower diligently repaying same, and the guarantor promptly bearing some of the costs and losses. The Central Bank of Barbados enumerates the advantages of a guarantee scheme to the borrower to include reduced collateral constraints; increased working capital; expansion of fixed assets, machinery and equipment; increased cash flow; increased sales and profit; borrowing at lowered interest rates and sometimes at longer terms; expansion, diversification and improvement of operations; job creation; new technology; new skills and new products. Aside other incentives, these should translate into farm investments that raise output, productivity, income and standard of living.

For the lender, the benefits may include reduced transactions costs and risks; added protection for loans; lower losses from loan defaults; larger loan volumes; better working relationships with small clients; opportunity to provide advisory services; additional businesses from existing clients; and new clients who may also buy into some of its other products. The guarantor would have succeeded in widening and easing access to credit among the target beneficiaries, thereby earning goodwill, among others. The medium to long-term goals would be poverty eradication or alleviation and the attainment of economic growth and development.

Guarantee schemes, leverage additional funds or "additionality" from the financial system because lenders make loans that otherwise would not have been made (Hollinger, 2004). Failure or limited success of these schemes is traced to paucity of capital to sustain the scheme operations (especially default in claims settlement by the guarantor and/or supervising agent); expensive, complicated and time-consuming administrative arrangements that discourage lenders; over-dependence on subsidies, such that some schemes were merely disguised credit subsidies (Hollinger, 2004). From another perspective, poor loan monitoring and supervision or the lack of it, either due to complacency or inadequacy of operational finance, is another major factor (Hassan, 1981; Ojo, 1985). Again, moral hazard is heavily entrenched in guarantee schemes, as the borrower is aware that the guarantor will make good some (or all) of his default to the lender.

From an older development economics perspective, according to ODA (1997), the objective of a guarantee scheme was less to correct a credit market imperfection, and more, as a Keynesian spending device, to stimulate growth in an economy where resources are not fully employed, through lending to small scale firms. In which case evaluation of the scheme would be based on whether firms of guaranteed borrowers actually grow faster than those of nonguaranteed borrowers (Boocock and Sharif, 1996; Rhyne, 1988). Broadly, though, an analysis of the overall impact of a guarantee programme must take into account the impact on each of the guarantor, the lender and the borrower. Meyer and Nagarajan (1996) present an extensive discussion of this issue in respect of developing countries.

For the guarantor, the impact depends on the objective of the scheme, its design, management and the extent to which it is used as a political tool. This 
throws up the desirable feature of creditworthiness which is essential for the survival of a guarantee scheme. For the lender, the impact goes beyond a matter of sustainability. Lenders should come to appreciate that there are good clients in the target group and begin to lend to them with softer terms. Also, a poorly designed fund may impact negatively on the lender, provoking adverse selection and negligence both in allocation and collection of loans. On the part of the borrower, additionality matters. It involves a pre- and post-guarantee situation analysis of access to loan, size of loan and farm performance, as well as a comparison with non-guaranteed borrowers.

\section{Arguments for and against Credit Guarantee Schemes (CGS)}

As would be expected, there has been on-going debates as to the justification for CGS. Proponents of CGS hold that in the absence of collateral, the guarantee fund provides guarantees that the loan would be secure. In case of default, the guarantee is executed and the lender recovers the loan. Gudger (1998) believes that guarantees are superior to other collaterals because they compensate for external factors such as slow and corrupt legal systems that delay the execution of collaterals, social and political pressures, etc. Secondly, CGS reduce lenders' reluctance and risk perception of the so-called "unbankable" groups whose family and business finances are often undifferentiated, with no appropriate accounting systems, and are highly vulnerable to harsh economic conditions and changes in the market, due to their seasonal and erratic cash flows.

Thirdly, since large volumes of small loans are unattractive to lenders owing to reduced profit margins and the lack of capacity to process small loans given that their scoring and evaluation technologies are designed for different target groups, guarantors do help in information collation and generation of adequate level of information useful for lenders, as well as in monitoring loans, thereby reducing lenders' cost. With time, the lenders should develop institutional capacity in the supply of small business credits. Fourthly, CGS advocates cite additionality effects, the extra lending that occurs to the target group that would have been impossible without the guarantee (Vogel and Adams, 1997; UNIDO, 2003).

Again, CGS are said to achieve considerable financial leverage which impact on financial deepening, because what is provided is guarantee capacity on the basis of a credible reserve fund of some kind, and not the loanable funds themselves. Sixth, with CGS, lenders are supposed to discover that the guaranteed borrowers are not as unprofitable or risky as they seemed to be. Hence, they are expected to make further loans to them and at softer terms after coming to this realization (DFID, 2005). Generally, a CGS, despite all its problems, as Nigrini and Schoombee (2002) conclude, still remains a viable way for the government to lower the normally high risk involved for banks in dealing with small and medium enterprises (SMEs), and in this way to entice them to serve SMEs.

In contrast, some scholars are of the view that it is doubtful whether CGSs are a first-best measure to address the market failures (such as information externalities and asymmetries, for instance) identified in the credit market. Some of the reasons that they advance are hereby presented. Firstly, creation of credit bureaus and strengthening the legal system may be better suited to overcome asymmetric information and small firms' difficulties in pledging their property as collateral. Secondly, they argue that lenders in developing economies in particular, are not interested in granting micro loans. In such countries, the characteristics of the financial market generate an excess of demand for loans and this makes micro lending unattractive to lenders. Also, the financial market is so closed that competition is relatively limited (UNIDO, 2003; Holden, 1996). Thirdly, there is no conclusive evidence that CGSs accomplish the financial and economic additionality and the financial sector changes they are designed to achieve. Since lending requires capital, which is scarce, the excessive demand for micro loans tends to surpass the amount available. And because no more can be done without further capital, CGSs do not produce additionality. Fourthly, CGSs are costly and unsustainable over time, as they tend to consume their capital quickly. Most guarantee funds do not have the large operational base able to cover costs and are at a loss as to whether to charge a costcovering premium or charge prices that are attractive for borrowers. If the guarantee is low-priced, the fund may lose capital for not breaking even. Resources utilized in supporting CGS would be effectively and efficiently used in a financial institution specialized in the target group (Vogel and Adams, 1997). Fifthly, due to experience and knowledge of their clients, lenders are better at evaluating risk than CGS. The guarantors are unlikely to have more experienced credit analysts than lenders; hence, they have fewer criteria to base their decisions on. If they use the same criteria applied by lenders, they would similarly reject loan applicants. Another argument raised against CGS is that neither lenders nor borrowers need a third party guarantee, as the lender could simply raise interest rates to cover risk, and borrowers actually need new lending technologies and operational methodologies which are appropriate for their growth and different from the commercial banking approach.

Further than these, one of the often cited downsides of the CGSs is the twin problem of moral hazard and adverse selection. According to Begg et al (2000), both are based on information asymmetries, the one on exploitation of privileged information to abuse an otherwise sound process, the other on taking actions that are considered discriminatory enough in the face of unavailable information. An aspect of moral hazard is the refusal of a borrower to repay following his knowledge that a government guarantee stands behind the bank. This explains why some CGSs, for example, in Pakistan, do not advise a borrower that his/ her loan has a guarantee attached. In the same vein, lenders may pass on what they know to be poorer quality parts of their existing portfolios, and/ or fail to adequately screen new propositions where most of the risk is foregone (ODA, 1997).

As is likely to happen, there is some evidence of moral hazard in the ACGSF. Very early in the scheme, Oboh (1981) showed that close to $11 \%$ of default was deliberate, and was premised on the certainty that the government, through the CBN, will pay up if they failed to repay. Farmers with certified capacity to repay loans defaulted for no just cause. Not even the added knowledge that the loans are drawn from private 
deposits and not a government grant, dissuades these defaulters. Studies report that such farmers become evasive and un-get-at-able, only to reappear when it seems the pursuit of them is over. This category of farmers who exploit the guarantee are the most difficult to handle.

When banks are faced with the bleak prospects of loan default, they simply stop advancing loans to customers who are thought to fall into the category of those who will not repay loans duly. In other words, they adversely select. Banks impose strict collateral requirements across board, irrespective of social or economic status of borrower. Presently, some banks in the ACGSF, notably Union Bank PLC, exhibits adverse selection behaviour by advancing ACGSF loans to only salaried farmers, that is, those in paid employment. Repayments are effected through regular deductions from borrower's monthly salary as it is paid in by the employer. The bank's decision seems vindicated by the almost total recovery recorded annually. Most deposit money banks and microfinance banks insist on a cash security of $25 \%$ of the required loan, preferably in a savings account on which the bank places a lien.

\section{Monetary Policy and Agricultural Credit}

Bank credit to agriculture is influenced by a number of factors. These include the peculiar nature of agriculture (seasonality, biological interaction, long gestation, fixity of assets, etc.), what could be grouped as internal factors (access to and costs of loanable funds, costs and returns of credit, loan to deposit ratio, size and structure of bank assets, etc.) and external factors (regulatory and policy requirements, etc.). Of interest to this study is the policy factor, the manipulation of various instruments by the monetary authorities in an effort to manage liquidity and confront inflation in the economy.

Most policy shocks work through to real economic activity via the credit channel which Bernanke and Gertler (1995) see as an amplification and propagation of the conventional interest rate channel of transmission. It has a firm's balance sheet approach and a bank lending approach. In the latter approach, any frictions in the asset-liability management of banks due to monetary shocks would be transmitted to real economic activity through the bank-dependent producers in the economy. Monetary policy affects the supply of loanable funds thereby impacting on the external finance premium of the bank-dependent borrower (firms and individuals). Thus, both interest rate and external finance premium effects explain output fluctuations (see Cavusoglu, 2002).

Two assumptions apply here, namely, that there are borrowers whose investment decisions depend on bank financing, and, the monetary authority is capable of influencing bank lending behaviour through monetary instruments (Kashyap and Stein, 1994). Specifically, frictions in the liability side of bank balance sheets due to costs of raising non-deposit external finance, for instance, would generate real effects on the asset side. The potency of a bank lending channel significantly depends on these real effects on assets, especially on bank loans (Cavusoglu, 2002). As far as can be ascertained, a tight monetary policy works as follows: a contraction in deposits (liability), first, causes a liquidation of security stocks, followed by a contraction in loans (assets) with a certain lag.

From a regime of direct controls during which the CBN set the maximum rate of credit expansion and how this was to be allocated to different sectors including the preferred sectors such as agriculture, the CBN moved towards a more deregulated monetary management after the introduction of the Structural Adjustment Programme (SAP) in 1986. A mix of indirect measures such as open market operations (OMO), cash reserve ratio (CRR) and minimum rediscount rate (MRR) have been employed. Increasing any of these has the effect of curtailing credit creation, stemming money supply and, particularly with the MRR, hiking the price of funds. How do banks react to this contraction?

Elumelu (2002) believes that they reduce credit to marginal customers, usually the small and medium enterprises; banks drastically reduce consumer finance; they concentrate on short term lending; and intensify deposit mobilization with higher rates and incentives. From the foregoing, agricultural customers are the most likely victims of a tight policy regime, since they are obviously among the marginal borrowers. In addition, their enterprises are often of medium to long gestation. Therefore, even in the face of guarantee of loans, monetary freeze reinforces the nature of agriculture to deny farmers and farm firms credit as banks prefer to lend scarce funds to sectors where they are guaranteed quicker returns and relatively lower risks.

\section{The ACGSF}

With a A3 billion capital base, the ACGSF is the foremost guarantee fund in Nigeria. Both deposit money banks (DMBs) and community banks (now known as microfinance banks, MFBs) lend under it, although the latter are only allowed to participate from 2004. Borrowers range from small-holder men and women farmers to large-scale limited liability enterprises engaged in agriculture or agro-related activities. The guarantor is the apex bank, the Central Bank of Nigeria (CBN). When, in addition, the guarantor is saddled with monetary and financial sector regulation, as it is with the $\mathrm{CBN}$, it becomes obvious that its statutory actions will have further consequences for the guarantee scheme.

Incentive-based programmes have been introduced into the scheme. Self Help Group (SHG) and Linkage Banking was adopted in 1991 to enthrone savings mobilization and group bargaining power as collateral and channel for accessing loans respectively (see Seibel, 1996). The Trust Fund Model (TFM) is an attempt to intermediate in the provision of collateral for loans. Individuals, groups, governments or corporate bodies place some funds in trust with a bank that is obliged to lend in multiples of that amount, to the loan beneficiaries. The Interest Drawback Programme (IDP), started in 2003, a subsidy of sorts that offers diligent borrowers a certain rebate - up to 40 per cent at the moment - on the interest paid. Finally, the allowance made for MFBs to participate in the scheme since 2004.

The various fine-tuning programmes are meant to improve the main performance measures of the scheme, namely volume of loans guaranteed and loans repaid. These measures only peaked in 2005 , when the number and value of loans guaranteed hit 46, 238 and N3.05 billion and the number and value of repaid guaranteed loans stood at 32, 549 and N1.86 billion 
respectively. Figure 1 shows the changes in value of loans guaranteed and repaid while Figure 2 shows those of changes in the numbers.

The peaks in the changes in value of loans guaranteed were recorded in 1979 (197.7\%, highest) which is the second year of operation of the scheme, 1985 (79.5\%), 1995 (59.2\%) and 2004 (79.3\%). The changes were negative in seven years, mostly so in $1984(-32 \%)$. For value of loans repaid, the significant peak years are $1986(87.7 \%), 1988$ (153\%) and 2001 $(96.2 \%)$, while the negatives are recorded in 1987 ($21.8 \%)$ and marginally in $1997(-1.5 \%)$. This situation is pictured in Figure 1.

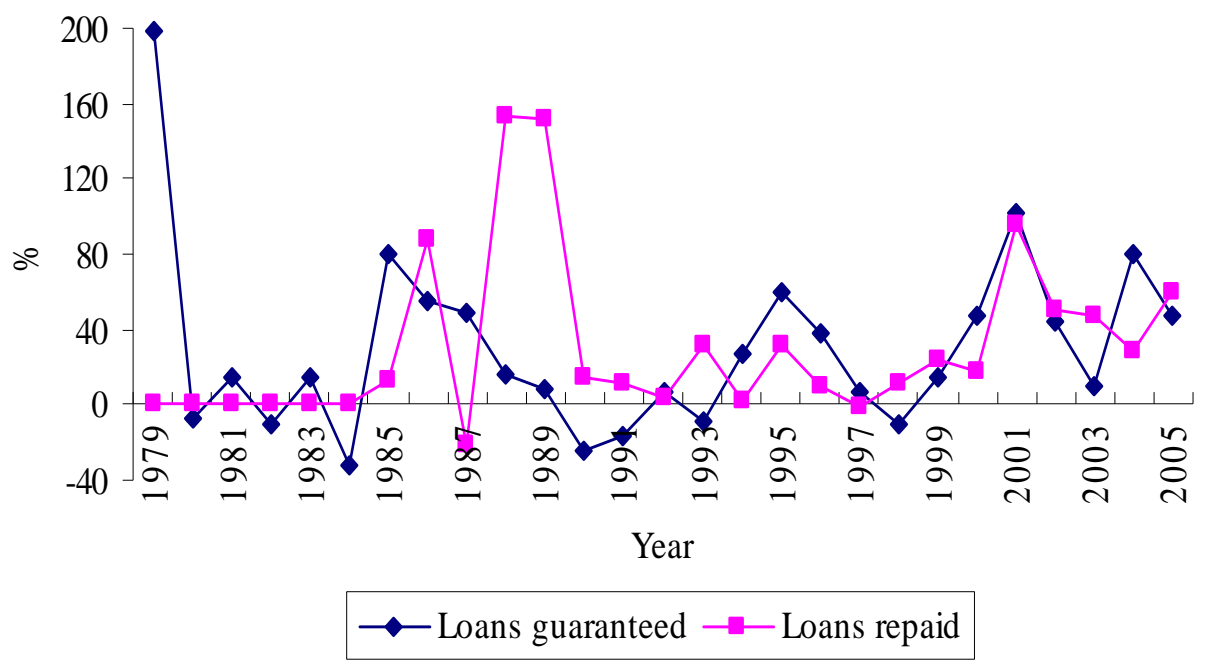

Figure 1: ACGSF: Changes in loans guaranteed and repaid

From figure 2, it is observed that the peaks in the number of loans guaranteed on the average corresponded to those in the value repaid, but there are nine negative years, with 1993 being most negative ($26.8 \%$ ). The number of loans repaid was highest in the 1987-1989 period and in 1999 and 2001 while 1998 ($11.2 \%$ ) was the year with the least change.

The figure shows that loans guaranteed are strongly related to loans fully repaid. A possible explanation is that most of the loans have duration of one year or less and this overlaps into the following year. This, in turn, is explicable by late disbursement of loans, which means that most loans guaranteed in a particular year are due for repayment the next year. This suggests, perhaps, that bank lending decisions in the new season is partly influenced by the volume of the previous year(s) loans recovered. The persistent drop in the number of loans after 1987 may have been due to deregulation, which saw most banks opt out of the scheme.

A key indicator of success in a guarantee scheme is the prompt settlement of claims once the guarantee is called up. This, in itself, becomes a performance yardstick. Hollinger (2004) is of the view that the ACGSF was surviving by defaulting in claims settlement. Among other reasons, most banks often attribute their disinterest in the programme to CBN's purported non-settlement of default claims. If loans fall into default and the guarantor equally fails to settle default claims made on it in respect of such bad loans, the logical thing banks do is to cut their exposure level or discontinue lending under the scheme if they have been doing so already and, for banks yet to lend, not to do so at all given their observation of the experience of participating banks.

The CBN maintains that default claims are being settled after all. Even when there was no board of directors for the Scheme following its dissolution in 1994, claims were still being settled under the administrative settlement arrangement (the board is statutorily mandated to approve such payments). For instance, in 2001 , by which time the board had not been reconstituted, the lending banks filed 406 default claims amounting to $\$ 9.56$ million. Out of these and the outstanding arrears of previous years, 436 claims valued N6.4 million were settled. Cumulatively, by the same year, 7,573 claims amounting to $\$ 307.2$ million had been submitted by banks while 3,685 claims valued N34.5 million had been settled, representing $48.7 \%$ and $11.2 \%$ of the total number and value of filed claims (ACGSF Annual Report, 2001). 


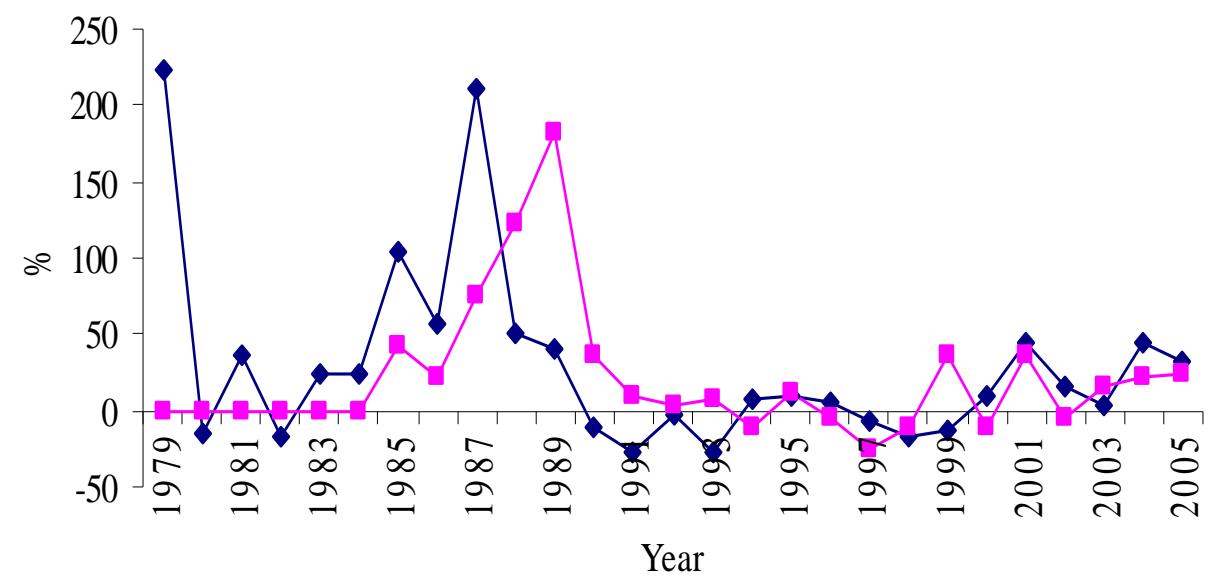

$\multimap$ Number of loans guaranteed $\rightarrow$ Number of loans repaid

Figure 2: ACGSF: Changes in number of loans guaranteed and repaid (1978-2005)

The relatively low settlement of claims is attributed to the fact that majority of the outstanding claims are those filed in respect of large-scale projects where collaterals for the loans were not foreclosed. Besides, many are said to be subjects of prolonged litigation. These arguments seem valid, and are strengthened by the evidence that some of these claims originated from banks that have long gone under. Anyway, the board has since been reconstituted to resume its responsibilities. Moreover, the scheme is not moribund, although it is generally believed that some of its provisions are somewhat obsolete and are being addressed by a bill before the national assembly. It is, however, clear that, firstly, the opportunity cost of policing loans to full repayment is settlement of default claims and, secondly, either of both has informational content useful to banks in determining their lending behaviour viz a viz the scheme.

Going by the average rate of marginal increases witnessed since 2000, it should take up to 25 years (or 2028) to catch up with the 1979 level. Suggestively, the ACGSF will be more relevant if 25 per cent, at the least, of all agricultural credit is served through its instrument. This should be the challenge for policy formulators as they continuously contemplate options that will reinvigorate the scheme.

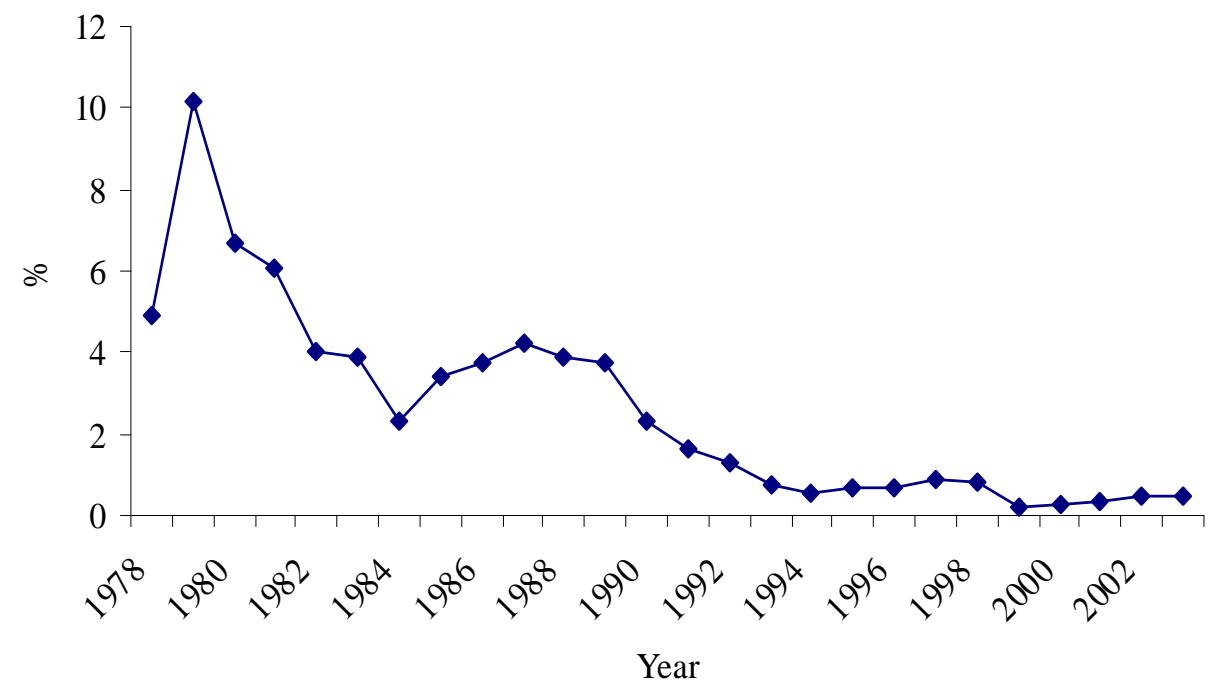

Figure 3: Guaranteed agricultural loans as proportion of total commercial banks credit to Agriculture 


\section{METHODOLOGY}

\section{The Model}

The study adopts a vector autoregression (VAR) modelling approach, used for forecasting systems of interrelated time series, and for analysing the dynamic impact of random disturbances on the system of variables. Within this joint framework, the variables are driven by random innovations or shocks, which represent sudden changes in the behaviour of economic agents and in the policy environment and/or stochastic events that affect credit market fundamentals. Consequently, one important feature of this approach is that it allows for the analysis of impulse response - which traces the effect of a one-time shock to one of the innovations on current and future values of the endogenous variables - and that of variance decomposition - which separates the variation in an endogenous variable into the component shocks to the VAR. The VAR model developed by Sims (1980) has been a standard approach to VAR modelling (see, for example, Mushtaq and Dawson, 2002; Nkang et al, 2007).

\section{Model Specification}

Assuming that the value of loans guaranteed under the ACGSF and the monetary policy variable are jointly determined (that is, endogenous to the system), we specify a VAR model relating the value of loans guaranteed $(\mathrm{vg})$, to the monetary policy variable $(\mathrm{mp})$, value of loans repaid (vr), number of loans both guaranteed (ng) and repaid (nr), following Sims (1980) as follows:

$$
z_{t}=\delta+A_{1} z_{t-1}+A_{2} z_{t-2}+\ldots A_{p-1} z_{t-p+1}+\varphi x_{t}+u_{t} \ldots
$$

Where:

$z_{t}$ is a $(n \times 1)$ vector of endogenous variables;

$x_{t}$ is a (q $\left.x 1\right)$ vector of exogenous variables

$\delta$ is a $(n \times 1)$ vector of parameters;

$A_{i}$ are $(n \times n)$ matrix of parameters;

$\varphi$ is a $(\mathrm{n} \times \mathrm{q})$ matrix of parameters

$u_{t}$ is an ( $\left.\mathrm{n} \times 1\right)$ vector of innovations (random disturbances), with $E\left(u_{t}\right)=0$ and which may be contemporaneously correlated, but are uncorrelated with their own lagged values and uncorrelated with all righthand side variables. In other words, $u_{t}$ is assumed white noise.

From the model specified above, $z_{t}=[v g, m p]^{\prime}$ that is a $(2 \times 1)$ vector of endogenous variables, while $x_{t}=[v r, n g, n r]^{\prime}$, denoting a $(3 \times 1)$ vector of exogenous variables, determined outside the system. Accordingly, the mathematical representation of the VAR in equation (1) can be written in terms of a VAR system of equations thus:

$$
\begin{aligned}
& \Delta \ln v g_{t}=a_{10}+\sum_{i=1}^{n} b_{1 i} \Delta \ln v g_{t-i}+\sum_{i=1}^{n} c_{1 i} \Delta \ln m p_{t-i}+d_{11} \Delta \ln v r_{t}+d_{12} \Delta \ln n g_{t}+d_{13} \Delta \ln n r_{t}+u_{1 t} \ldots \ldots \ldots \ldots . . . \\
& \Delta \ln m p_{t}=a_{20}+\sum_{i=1}^{n} b_{2 i} \Delta \ln v g_{t-i}+\sum_{i=1}^{n} c_{2 i} \Delta \ln m p_{t-i}+d_{21} \Delta \ln v r_{t}+d_{22} \Delta \ln n g_{t}+d_{23} \Delta \ln n r_{t}+u_{2 t} \ldots \ldots . .
\end{aligned}
$$

Where: " $\Delta$ " and "In" are the difference and natural logarithmic operators respectively, while $a_{i j}, b_{i j}, c_{i j}$ and $d_{i j}$ are parameters to be estimated.

\section{Model Implementation Procedure}

We began with the assessment of the time series properties of the data by subjecting them to stationarity tests using the Augmented Dickey-Fuller (ADF) and Phillips-Perron (PP) criteria (see, Dickey and Fuller, 1981; Said and Dickey, 1984 for a detailed discussion of the tests procedures). This is necessary since many economic time series are non-stationary at their levels, thus, regressions between such data are spurious. The presence of a unit root in the autoregressive representation of a time-series leads to non-stationarity and such series, said to be integrated of order one $(I(1))$, must be first-differenced to render them stationary (or integrated of order zero).

Next, Granger-Causality tests were carried out to show the relationship between the variables in terms of precedence. This was buttressed by a correlation matrix that shows the direction of such relationships. A Jarque-Bera test for normality was also carried out to provide some information on the distribution of the mean and variance of each series. Generally, independently and identically distributed series with zero mean and constant variance are desirable for efficient results. We then estimated the VAR alongside important diagnostics followed by impulse response and variance decomposition analyses.

\section{The Data}

Annual observations on five series namely, minimum rediscount rate, value of loans guaranteed, number of loans guaranteed, value of loans repaid and number of loans repaid, from 1978 (when the ACGSF became operational) to 2005, were used for the analysis. They were sourced from the ACGSF Statistics and the Financial Statistics of the CBN Statistical Bulletin as well as the Nigerian Financial Indicators publication of the $\mathrm{CBN}$. The data are accessible electronically from the CBN website, www.cenbank.org.

The study, adopts value of loans guaranteed as the dependent variable, since it approximates credit. Number of loans guaranteed, the number and the value of loans repaid are entered as regressors because of their proximities to the philosophy underlying the SHG, TFM and IDP, and because they are likely to be determined outside the bank. For instance, whereas banks set the amount of credit, they hardly determine how many loan applications they get and, hence, how many customers to be availed, thus making the variables to be assumed exogenous.

Again, the choice of the minimum rediscount rate as the monetary policy variable is predicated on the argument that data on its series have been readily available over time, and especially because it has a direct effect on the cost of bank funds. Indeed, presently, banks are obliged to charge loan interest rates of a margin not higher than 4 per cent above this rate. This variable (as well as the value of loans guaranteed) is assumed endogenous given that the rate of interest may well vary with the size of the loan and the 
economic characteristics of borrower that affects the probability of repayment.

\section{RESULTS AND DISCUSSION}

Table 1 shows the results of the normality and Granger-Causality tests and the correlations matrix of the variables. With the exception of $\mathrm{vg}$ and $\mathrm{vr}$, all variables are normally (independently) distributed as indicated by the Jarque-Bera (J-B) Statistic. The correlations matrix suggests that there is a weak negative relationship between the monetary policy variable $\mathrm{mp}$ (minimum rediscount rate) and the values of credit guaranteed, vg and repaid, vr. With respect to Granger-Causality, it is interesting to see that vg granger-causes $\mathrm{ng}$, $\mathrm{nr}$ and $\mathrm{vr}$ but is itself not granger caused by any of the other variables. All the relationships with statistical significance are unidirectional except for that between $\mathrm{vr}$ and $\mathrm{nr}$ which is two-way. Granger-Causality measures precedence and information content but does not in itself indicate causality in the more common use of the term.

Furthermore, test statistics of the unit root test are reported in Table 2. All the variables (in logs) are I(1) apart from nr which is I(2). For nr, the null hypothesis of non-stationarity is rejected at $10 \%$ confidence interval under the Augmented Dickey-Fuller Test after firstdifferencing but not rejected under the Phillips-Perron Test at the same level. After differencing twice, however, the variable convincingly attains stationarity at $1 \%$ confidence interval under both tests. A case of this nature re-enforces the decision to employ more than one test here, at least for the complementarity of purpose and for the avoidance of doubt.

The results suggest that our VAR system be estimated by transforming the variables from the levels to differences. An unrestricted VAR is thence estimated, with the following output in Table 3 . The table also reports the post-estimation tests of good specification.

Table 1: Results of Normality and Granger Causality tests and the correlations matrix

\begin{tabular}{cccccccc} 
Test & \multicolumn{2}{c}{ Normality Test } & \multicolumn{5}{c}{ Correlations Matrix/ Granger Causality Test $\left(^{*}\right)$} \\
Series & J-B Stat & Prob. & $\mathrm{mp}$ & $\mathrm{Ng}$ & $\mathrm{Nr}$ & $\mathrm{vg}$ & $\mathrm{Vr}$ \\
$\mathrm{mp}$ & 0.865 & 0.648 & 1 & 0.315 & 0.405 & -0.043 & -0.014 \\
$\mathrm{ng}$ & 1.046 & 0.592 & 0.315 & 1 & 0.718 & 0.694 & 0.685 \\
$\mathrm{nr}$ & 0.068 & 0.966 & 0.405 & 0.718 & 1 & 0.725 & 0.753 \\
& & & & & & & $(2.639)^{*}$ \\
$\mathrm{vg}$ & $84.768^{* * *}$ & 0.000 & -0.043 & 0.694 & 0.725 & 1 & 0.993 \\
& & & & $(2.869)^{*}$ & $(3.573)^{* *}$ & & $(11.027)^{* * *}$ \\
$\mathrm{vr}$ & $35.699^{* * *}$ & 0.000 & -0.014 & 0.685 & 0.753 & 0.993 & 1
\end{tabular}

$*$, ** and ${ }^{* * *}$ indicate significance at $90 \%, 95 \%$ and $99 \%$ respectively. Figures in bracket are the (Wald) F-statistics for the Granger causality test at three lags, with only the significant results reported. In reading the table, the variable under the test series column is hypothesized to granger cause the one in the correlations matrix/granger causality test column

Table 2: Unit root test of variables

\begin{tabular}{lllllll}
\multicolumn{5}{c}{ Augmented Dickey-Fuller Test } & \multicolumn{3}{c}{ Phillips-Perron Test } \\
& Level & $\Delta$ & $\Delta^{2}$ & Level & $\Delta$ & $\Delta^{2}$ \\
$\mathrm{Mp}$ & -2.357 & $-6.705^{* * *}$ & - & -2.703 & $-6.797^{* * *}$ & - \\
$\mathrm{Vg}$ & 1.474 & $-5.147^{* * *}$ & - & 0.172 & $-5.076^{* * *}$ & - \\
$\mathrm{Vr}$ & -0.407 & $-4.336^{* * *}$ & - & -0.407 & $-4.336^{* * *}$ & - \\
$\mathrm{Ng}$ & -1.052 & $-4.578^{* * *}$ & - & -2.225 & $-4.596^{* * *}$ & - \\
$\mathrm{Nr}$ & $-3.089^{* *}$ & $-2.723^{*}$ & $-5.576^{* * *}$ & $-2.793^{*}$ & -2.280 & $-5.567^{* * *}$
\end{tabular}

$90 \%, 95 \%$ and $99 \%$ significance levels are indicated by $*,{ }^{* *}$ and ${ }^{* * *}$ respectively 


\begin{tabular}{|c|c|c|c|c|c|c|c|}
\hline \multirow[b]{2}{*}{ Intercept } & & \\
\hline & $\Delta \mathrm{mp}_{\mathrm{t}-1}$ & $\Delta v r$ & \multicolumn{2}{|l|}{$\Delta \mathrm{ng}$} & $\Delta^{2} \mathrm{nr}$ & \multicolumn{2}{|l|}{$\Delta \mathrm{vg}_{\mathrm{t}-1}$} \\
\hline $\begin{array}{l}0.0502 \\
(0.0512)\end{array}$ & $\begin{array}{l}-0.0151^{*} \\
(0.0083)\end{array}$ & $\begin{array}{l}0.2888^{* *} \\
(0.1279)\end{array}$ & \multicolumn{2}{|c|}{$\begin{array}{l}0.6071^{\star \star *} \\
(0.1149)\end{array}$} & $\begin{array}{l}0.1486 \\
(0.1201)\end{array}$ & \multicolumn{2}{|l|}{$\begin{array}{l}0.4028^{* * *} \\
(0.1326)\end{array}$} \\
\hline \multicolumn{4}{|c|}{$R^{2}=0.81 \quad R_{\text {Adj }}^{2}=0.74 \quad$ F-stat $=11.3032^{* * *}$} & \multicolumn{3}{|c|}{ Std. Error of Eqn. $=0.1332$} & \\
\hline \multirow{2}{*}{\multicolumn{4}{|c|}{$\begin{array}{l}\text { Diagnostics } \\
\text { Lag Exclusion Wald Test }\end{array}$}} & Test & Stat. & $p$-values & Remarks \\
\hline & & & & $x^{2}(F)$ & 36.0589 & 0.0000 & \\
\hline \multicolumn{4}{|c|}{ Jarque-Bera Residual Normality Test } & $x^{2}(F)$ & 3.6669 & 0.4530 & \\
\hline \multicolumn{4}{|c|}{ Residual Portmanteau autocorrelation Test } & Q-Stat & 6.8351 & 0.1162 & At 2 lags \\
\hline \multicolumn{4}{|c|}{ Serial Correlation LM Test } & LM-Stat & 5.3734 & 0.2511 & At 1 lag \\
\hline \multicolumn{4}{|c|}{ Heteroskedasticity Test } & $x^{2}(F)$ & 39.2264 & 0.1207 & \\
\hline $\begin{array}{l}\text { Pairwise } \\
\text { Exogeneit }\end{array}$ & granger & causality/ & Block & & 3.3058 & 0.0690 & \\
\hline
\end{tabular}

\begin{tabular}{lcllccc} 
& & \multicolumn{4}{c}{ Other Tests } \\
Lag Order Selection & LR & FPE & AIC & SC & HQ \\
Test & 18.0506 & $0.41434^{\#}$ & $4.749996^{\#}$ & $5.346484^{\#}$ & $4.850946^{\#}$ \\
Stability Condition Test & Root & -0.460921 & 0.405176 & VAR satisfies the \\
& Modulus & 0.405176 & 0.460921 & stability condition
\end{tabular}

Significance at $1 \%, 5 \%$ and $10 \%$ depicted by ${ }^{* * *},{ }^{* *}$ and ${ }^{*}$ respectively. For the lag order selection criteria, the reported values for the Lkelihood Ratio (LR), Final Prediction Error (FPE), Akaike Information Criterion (AIC), Schwartz Criterion (SC) and Hannan-Quinn Criterion ( $\mathrm{HQ})$ are at one lag which is preferred $\left({ }^{\#}\right)$ over other lag structures.

All the coefficients are correctly signed and the model accounts for a high proportion $(81 \%)$ of the variation in value of loans guaranteed under the ACGSF. Furthermore, the specification test results are all favourable. The roots of the VAR lie within the unit circle, no evidence of serial correlation and homoskedasticity and the model passes the test of stability. The residuals are equally multivariate normal and the variables are jointly significant. The model may then be used, within the limits of the analysis, to draw conclusions.

Contemporaneous value of loans repaid exerts some fairly strong influence on banks' decision to apply for more guarantees in the year. A 10 per cent increase in value of recovered loans make good an additional nearly 3 per cent in value of loans guaranteed. This is just as well since banks would wish to recover most previous loans before granting new ones and the level of the former informs their preparedness to do so and also the size of the new global limit. As for the contemporaneous number of loans guaranteed, it enters as expected, with a strong relationship to loans guaranteed. Logically, the higher the number of loans guaranteed, all things being equal, the higher the value of loans guaranteed. A percentage increase in number of loans guaranteed (ng) expands aggregate value of guaranteed credit by 0.6 per cent.

Number of loans repaid is not significant, and this for the likely reason that banks are more concerned with the amount of recoveries and less with the number. What affects banks' balance sheets is the value of assets (including credit), not the number per se. All the same, an increase in guaranteed credit of 1.4 per cent is traceable to a percentage increase in number of loans repaid in the previous period.

The monetary policy variable $(\mathrm{mp})$, proxied by the minimum rediscount rate, shows a weak significance. The time lag may have been enough time for banks to adjust and this wears down the effect of the change. However, it still suggests that it affects guaranteed credit outlay by banks, and negatively so. A 100 basis points increase in the rate leads to a shrinking of guaranteed bank credit to agriculture by just less than a fifth of a percentage point. This may be considered infinitesimal, but when viewed in relation to the likely shutting out of more marginal borrowers especially in agriculture, then there is cause for concern. This might be possible in 90 per cent of the time.

\section{Impulse response and variance decomposition}

Figure 4 shows the impulse response functions employed in analysis. An initial shock of monetary policy causes a further drop in value of credit guaranteed by 0.02 per cent from

-0.08 to -0.1 per cent in the second year. There is an attempt at recovery over the next three years to the point where there is a zero effect. This latest situation persists beyond the fifth year. Conversely, shocks of value of credit guaranteed to monetary policy have no effect whatsoever. Shocks of the variables to themselves cut quite a different picture. While the response of credit guaranteed to itself declines from 0.1 per cent in the first year to zero by the fifth year, that of minimum rediscount rate onto itself fluctuates between 4.5 and -2.0 per cent before tapering to zero after five years.

The largely negative response of guaranteed credit to unexpected rises in indirect monetary instruments of policy is an affirmation of the relationship between both variables as shown in the correlations matrix and the regression coefficients. Hence, an unexpected rise in the minimum rediscount rate is conclusively associated with dropping guaranteed credit to agriculture. 
The decomposed variances, on the other hand, are pictured on Table 4. It is easily seen that 36 per cent of the forecast error of the value of guaranteed credit is due the minimum rediscount rate in the first horizon (year) and 55 per cent in subsequent horizons. 64 per cent and $44 \%$ of the variance of this error is due to guaranteed credit itself, in the first year and in subsequent years respectively.

\section{Impulse Response (Response to Cholesky One S.D. Innovations \pm 2 S.E.)}

Response of value of credit guaranteed to minimum rediscount rate

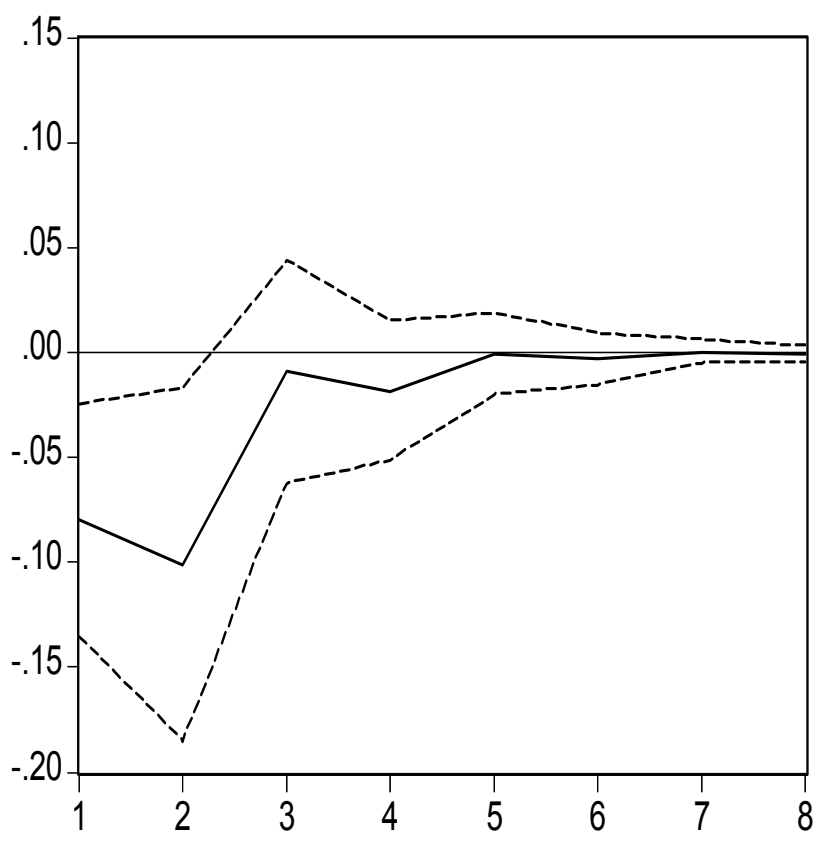

Response of minimum rediscount rate to minimum rediscount rate

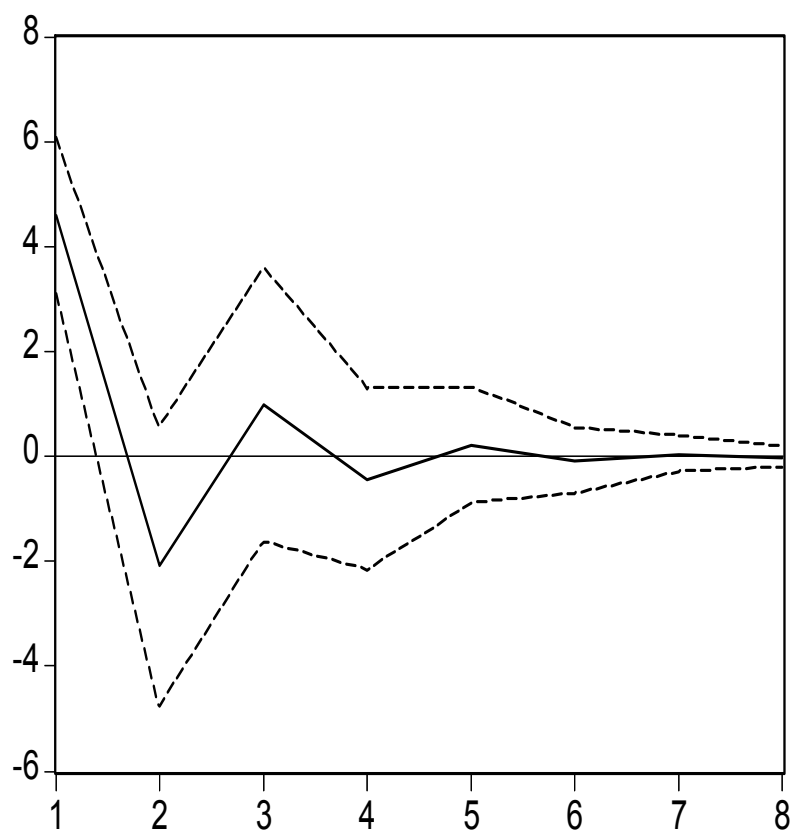

Response of value of credit guaranteed to value of creditguaranteed

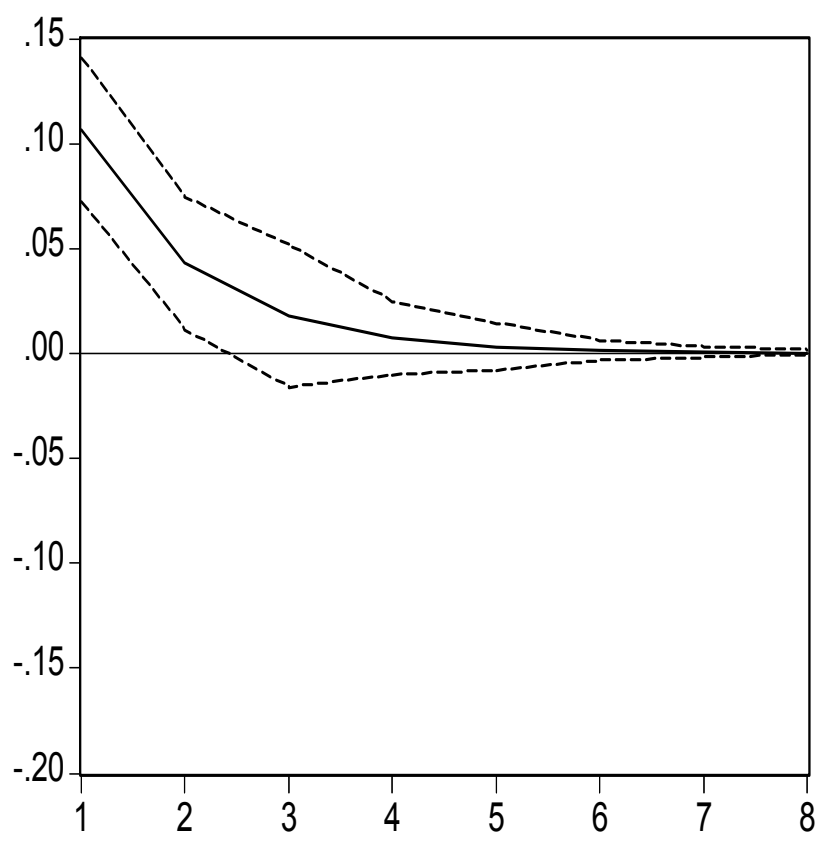

Response of minimum rediscount rate to value of credit guaranteed

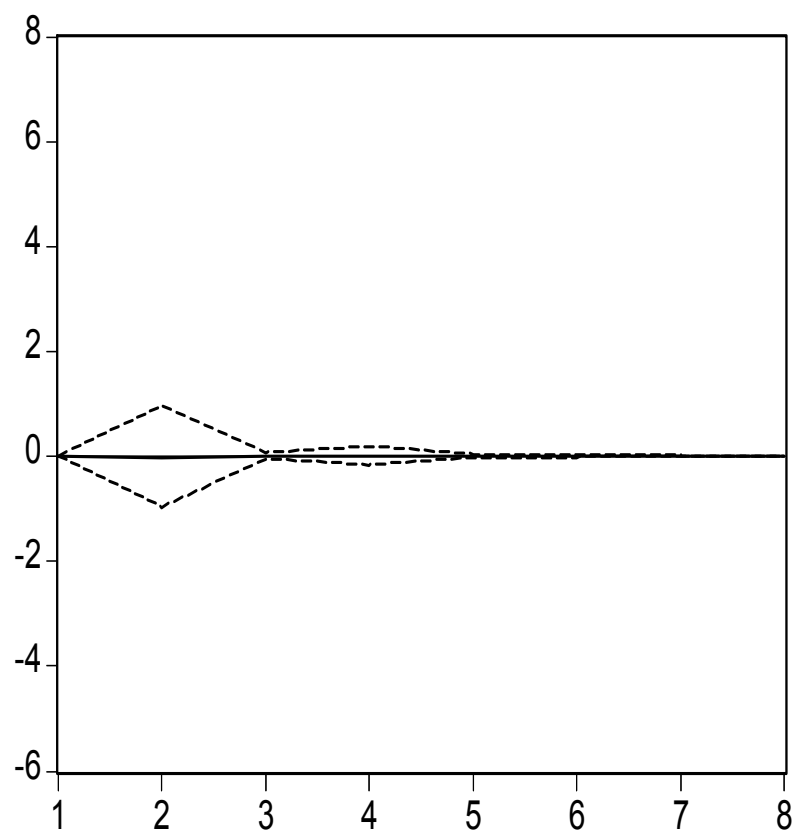

Figure 4: Impulse response graphs of shocks to value of credit guaranteed and minimum rediscount rate (with asymptotic standard errors) 


$\begin{array}{cccc}\begin{array}{c}\text { Table 4: Variance decomposition of value of guaranteed credit } \\ \text { Forecast } \\ \text { Horizon }\end{array} & \begin{array}{c}\text { Forecast } \\ \text { Variance decomposition }\end{array} & \begin{array}{c}\text { Standard Errors } \\ \text { (percentage points } \\ \text { Vg }\end{array} & \begin{array}{c}\mathrm{Mp} \\ 1\end{array} \\ & 4.5936 & 63.9542 & 36.0457 \\ 3 & 5.1424 & 44.5929 & 55.4070 \\ 5 & 5.1658 & 44.2031 & 55.7969 \\ 7 & 5.1668 & 44.1887 & 55.8108\end{array}$

\section{POLICY IMPLICATIONS}

Consideration has here been given to developing a model that best explains the operations of the Agricultural Credit Guarantee Scheme Fund (ACGSF). Building up from a vector autoregression (VAR) analysis, certain results have been arrived at, with implications for present and future courses of action.

The managers of the ACGSF must intensify efforts at loan recovery. This is possible through efficient project management processes from farm appraisal to regular monitoring. It should be remembered that if a tenth of previous loans are outstanding, banks are likely to cut participation in the scheme by almost $3 \%$, all things being equal. Personnel require quality training in the areas of loan appraisal, credit administration, as well as improved knowledge on the basics and new techniques of agricultural production, since their work would sometimes overlap into an extension role. Regular courses are therefore advocated. This should plug knowledge gaps in this respect. Also, all material and logistic support for effective loan monitoring should be committed to the disposal of the field personnel.

We cannot say for certain what the effects of SHG, TFM and MFB participation are, but an increase in number of loans repaid seems to be promoted by the IDP. As such, efforts should be made to publicize it widely. Publication of the figures of rebate paid out so far, and the placement of each subsequent claims payment in the media, would go a long way in this regard. While the IDP is commendable, it should be borne in mind that it is still a form of subsidy, with attendant costs on public coffers and no economic returns. It is subject to abuse in that banks may make frivolous loans if not checked, only to claim the interest rebate on "full repayment" as a means of boosting their profit. There are the remote problems that it may hamper the proper functioning of the credit market to the extent that interest charges become exorbitant with the knowledge that borrowers would receive a compensatory payment and that monetization of the rebate by customers could cause inflation.

There would likely be an increase in credit guaranteed if banks can access the discount window at favourable terms. That high interest rates hurt agriculture is not in doubt. It has also been identified that high rediscount rates lead to a reduction in credit to the sector. The CBN is thus called upon to tread softly in its liquidity management job so that it does not choke out both the farmers from access to credit and the banks from granting same. The situation with guaranteed loans is already that displeasing. Tightening of monetary policy may have to be tempered with policies promoting financial deepening and competition that would drive interest rates down to single digits. This, by all standards, is already being done through banking consolidation and microfinance reforms. As these reforms proceed, farmers and marginal borrowers should accumulate assets and increase their incomes. Gradually, there would be no need for the IDP or the guarantee. But, that is still yet afar off.

In the meantime, emphasis on volume of loans guaranteed should shift to measures of real (scale) activity at the firm level such as output of farmers under guarantee, their incomes and labour employment on such farms. These could form the basis of assessment of ACGSF personnel. In future, the issue of additionality and financial leverage might have to be addressed frontally as it concerns the ACGSF. By extension, the sustainability of the scheme without state support should be explored in the long run, to make for greater efficiency in costs.

Finally, given the low proportion of agricultural credit under guarantee, efforts should be made by the Fund to iron out grey areas in its operations by adopting new designs, features and technologies that are appropriate to reality, such as extending the upper limit of amounts for guarantee to embrace larger loans, expediting action on settlement of verified outstanding claims and promptly settling new ones, developing capacity to process and approve guarantees and default claims and other related processes on-line, regularly mounting training for lending banks, etc. These are expected to renew lenders' confidence in the scheme.

\section{REFERENCES}

Agricultural Credit Guarantee Scheme Fund., 2001, Annual report and statement of accounts, Central Bank of Nigeria.

Atieno, R., 2001. Formal and informal institutions' lending policies and access to credit by smallscale enterprises in Kenya: an empirical assessment. African Economic Research Consortium, Research Paper 111

Begg, D., Fischer, S. and Dornbusch, R., 2000. Economics. McGraw Hill Publishing Company, England.

Bernanke, B. and Gertler, M., 1995. Inside the black box: the credit channel of monetary policy transmission. J. Econ. Perspective, 9: 27-48.

Besley, T., 1994. How do market failures justify intervention in rural credit markets? The World Bank Research Observer, 9: 27-47 
Boocock, G. and Sharif, M. N. N., 1996. Loan guarantee schemes for SMEs: the experience in Malaysia. SED J., 7: 25-36.

Çavuşoğlu, A. T., 2002. Credit transmission mechanism in Turkey: an empirical investigation. Economic Research Centre Working Papers in Economics, 02-03.

Department for International Development., 2005. Do credit guarantees lead to improved access to financial services: recent evidence form Chile, Egypt, India and Poland. Policy Division Working Paper, 05-02.

Dickey, D. A. and Fuller, W. A., 1981. Likelihood ratio statistics for autoregressive time series with a unit root. Econometrica, 49: 1057-1072.

Elumelu, A., 2002. Interest and exchange rates management in Nigeria: a macroeconomic implication. Paper presented at Ambrose Ali University Alumnus Guest Lecture Series of the Department of Economics, Ekpoma,

Food and Agriculture Organization, 2006. Rural credit guarantee schemes: a financial instrument for agriculture and rural development. Workshop on same issue, summary of report, Budapest,.

Gudger, M., 1998. Credit guarantees: an assessment of the state of knowledge and avenues of research. Working Document, Food and Agriculture Organization, Rome

Hassan, U., 1981. A positive approach to economics of agricultural and rural development in Nigeria. J. Federal Department of Rural Development, 2: 33-47.

Holden, P., 1996. Collateral without consequence: the causes and effects of financial underdevelopment in Latin America. Paper presented. At Round Table of Credit Guarantee Schemes, Inter American Bank, Washington, D.C.

Hollinger, H., 2004. Financing agricultural term investment in: Agricultural finance revisited series, 7. Food and Agriculture Organization of the United Nations and the German Technical Co-operation.

Kashyap, A. K. and Stein, J. C., 1994. Monetary policy and bank lending, in: N. Gregory Markiw (ed.), Monetary Policy, NBER Studies in Business Cycles, 29, Chicago: University of Chicago Press, 221-256.

Meyer, R. L. and Nagarajan, G., 1996. Evaluating credit guarantee programs in developing countries. Rural Finance Program, Ohio State University, Economics and Sociology Occasional Paper, (2322).
Mushtaq, K. and Dawson, P. J., 2002. Acreage response in Pakistan: a co-integration approach. Agric. Econ., 27: 111-121

Navajas, A. R., 2001. Credit guarantee schemes: conceptual frame. Financial System Development Project, GTZ/FONDESIF, unpublished.

Nigrini, M. and Schoombee, A., 2002. Credit guarantee as an instrument to promote access to finance for small and medium enterprises: an analysis of Khula Enterprise Finance Limited individual credit guarantee scheme. Development Southern Africa, 19: 735-750.

Nkang, N. M, Ndifon, H. M. and Edet, E. O., 2007. Maize supply response to changes in real prices in Nigeria: a vector error correction approach. Agric. J., 2: 419-425

Oboh, D. O., 1981. Problems of agricultural finance in Nigeria in: Agricultural credit and finance in Nigeria, eds. Ojo, M. O., Eduordu, C. C., Akingbade, J. A. Central Bank of Nigeria, Lagos

Overseas Development Organization, 1997. Credit guarantee schemes for small business lending: a global perspective. Graham Bannock and Partners Ltd.. London

Ojo, M. O., 1985. Agricultural credit policies in Nigeria: a review of achievements, problems and prospects. Central Bank of Nigeria Economic and Financial Review, 23: 43-57.

Reichmuth, M., 1997. Credit guarantee schemes for small enterprises: an assessment. Warsaw, Workshop on Polish Agricultural and Rural Credit Guarantees, presented paper.

Rhyne, E. H., 1988. Small business and SBA loan guarantees: subsidizing the weak or bridging a credit gap? New York: Quorum Books.

Said, S. E. and Dickey, D. A., 1984. Testing for unit roots in autoregressive-moving average models of unknown order. Biometrica 71, 599-607.

Seibel, H. D., 1996. Transforming rural finance in Africa: the role of AFRACA in linkage banking and financial systems development. AFRACA Newsletter, December 22.

Sims, C.A., 1980. Macroeconomics and reality. Econometrica, 48:1-49.

Stiglitz J. and Weiss, A., 1981. Credit rationing in markets with imperfect information. American Economic Review, 71: 393-410

United Nations International Development Organization, 2003. Credit guarantee schemes for small enterprises: an effective instrument to promote private sector-led growth? Downloadable at http://www.unido.org/en/doc/18252. 
Vogel, R. C. and Adams, D. W., 1997. Costs and benefits of loan guarantee programs. The Financier, May 4: 22-29. 